\begin{tabular}{|l|l|l|}
\hline Received : June 2018 & Accepted: July 2018 & Published : September 2018 \\
\hline
\end{tabular}

\title{
Nilai Intrisik Saham PT Bank Mandiri (Persero) Tbk dengan Metode Relative Valuation
}

\author{
Prihatiningsih \\ Jurusan Akuntansi Politeknik Negeri Semarang \\ atin_weis@yahoo.com
}

\begin{abstract}
This study aims to determine the intrinsic value of PT. Bank Mandiri (Persero), Tbk shares with code shares BMRI, the shares condition, and decisions that can be taken under these conditions. Valuation method used in this study is Relative Valuation. The steps fundamental analysis are macroeconomic analysis, industry analysis and company analysis required to make investment decision on BMRI shares. From the results of study note even the BMRI shares price is overvalued than intrinsic value. Risk seeker investors who haven't BMRI shares can buy it, and risk seeker investors who have PTPP shares can hold it in their portfolio. Risk averse investors who have the BMRI shares can sell it, and risk averse investors who haven't BMRI shares can hold to buying.
\end{abstract}

Keywords: valuation, intrinsic value, relative valuation.

\begin{abstract}
Abstrak
Penelitian ini bertujuan untuk mengetahui nilai intrinsik saham PT. Bank Mandiri (Pesero), Tbk dengan kode saham BMRI, kondisi saham, dan keputusan yang dapat diambil berdasarkan kondisi tersebut. Data yang digunakan adalah data sekunder meliputi data harga saham dan laporan keuangan perusahaan yang divaluasi menggunakan metode Relative Valuation. Tahapan analisis fundamental berupa analisis makro ekonomi, analisis industri serta analisis perusahaan untuk membantu pengambilan keputusan investasi pada saham BMRI. Berdasarkan hasil penelitian ini diketahui bahwa harga saham BMRI overvalue terhadap nilai intrinsiknya. Risk seeker investors yang belum memiliki saham BMRI dapat membeli saham tersebut, apabila risk seeker investors memiliki saham BMRI dapat menahan saham tersebut dalam portofolio. Risk averse investors yang memiliki saham BMRI dapat menjual saham tersebut, dan risk averse investors yang tidak memiliki saham BMRI dapat menahan keputusan untuk membeli saham tersebut.
\end{abstract}

Kata kunci: valuasi, nilai intrinsik, relative valuation.

\section{Pendahuluan}

Investasi merupakan bagian dari komitmen atas sejumlah dana atau sumber daya lainnya yang dilakukan pada saat ini, dengan tujuan untuk memperoleh sejumlah keuntungan di masa yang akan datang. Jenis investasi yang ditawarkan berupa investasi pada real asset dan investasi financial asset. Menurut Tandelilin (2007), salah satu tempat untuk melakukan investasi financial asset adalah di Pasar Modal atau Bursa Efek Indonesia.

Pada tahun 2016 sebanyak 539 perusahaan telah terdaftar di Bursa Efek Indonesia dan memperdagangkan saham perusahaan tersebut (http://idx.co.id, 2016). Jenis saham yang diperdagangkan lebih dari satu, sehingga memungkinkan investor untuk dapat memilih saham yang sesuai dengan profil karakteristik investor. Investor yang ingin menginvestasikan dananya pada saham perlu mengetahui apakah saham yang dipilih layak menjadi alternatif dalam menginvestasikan dana yang dimiliki tersebut. Untuk membuat keputusan dalam investasi pada saham maka diperlukan suatu penilaian terhadap saham yang akan dipilih yang bertujuan untuk memprediksikan tingkat pengembaliaan yang diharapkan investor dan menentukan saham tersebut mengalami overvalue atau undervalue. 
Penilaian saham secara fundamental memiliki tiga jenis nilai yaitu nilai buku, nilai pasar dan nilai intrinsic. Menurut Jogiyanto (2010) nilai buku per lembar saham menunjukkan aktiva bersih (net assets) yang dimiliki oleh pemegang saham dengan memiliki satu lembar saham. Nilai pasar adalah harga saham yang terjadi di pasar bursa pada saat tertentu yang ditentukan oleh pelaku pasar. Nilai intrinsik adalah nilai saham yang sebenarnya atau seharusnya terjadi, sedangkan penilaian saham secara teknikal untuk menentukan saat yang tepat untuk memasuki pasar.

Penelitian sebelumnya yang dilakukan oleh Noor dan Satyawan (2014) mengenai penilaian harga saham dengan metode yang digunakan dividend discounted model (DDM) dan Price Earning Ratio (PER). Harga saham PT. Multi Bintang Indonesia, Tbk apabila dihitung dengan pendekatan Dividend Discounted Model pertumbuhan tidak konstan (ganda) periode 2010 menunjukkan kondisi undervalued dan investor dapat mempertahankan saham PT. Multi Bintang Indonesia, Tbk dalam portofolio atau membeli saham tersebut, sedangkan tahun 2011 sampai dengan 2013 dinilai overvalued apabila dihitung dengan pendekatan Dividend Discounted Model pertumbuhan tidak konstan (ganda). Hasil penelitian menggunakan Price Earning Ratio menunjukkan harga saham PT. Multi Bintang Indonesia, Tbk pada tahun 2010 berada pada kondisi overvalued, dan tahun 2011 sampai tahun 2013 harga saham MLBI berada pada kondisi undervalued.

Tumangger dan Moeliono (2015) juga melakukan penelitian tentang penilaian harga saham PT. Bank Tabungan Negara (Persero) Tbk. Metode penilaian harga saham yang digunakan adalah Dividend Discounted Model (DDM). Berdasarkan hasil penelitian ini diketahui bahwa nilai wajar saham BBTN sebesar Rp174,7. Dari hasil nilai wajar tersebut yang kemudian dibandingkan dengan harga pasar tiap saham pada bulan Januari 2014 dapat disimpulkan bahwa saham Bank Tabungan Negara dinilai overvalued atau terlalu mahal.

Saham PT. Bank Mandiri, Tbk (BMRI) saat ini menjadi salah satu saham sektor perbankan yang paling banyak diminti oleh para investor setelah saham PT. Bank Rakyat Indonesia,Tbk (BBRI), dengan harga tertinggi sepanjang tahun $2016 \mathrm{Rp} 12.475$ dan harga terendah Rp 8.175, sementara saat ini saham BMRI diperdagangkan Rp 13,375 per lembar saham berarti sudah mengalami $1.881,48$ persen sejak IPO. Kronologi pencatatan saham BMRI adalah sebagai berikut:

Tabel 1. Kronologi Pencatatan Saham BMRI

\begin{tabular}{lcc}
\hline \multicolumn{1}{c}{ Jenis Pencatatan } & Jumlah Saham (Lembar) & Tanggal Pencatatan \\
\hline Saham Perdana @ Rp675,- & 2.900 .000 .000 & 14-Jul-2003 \\
\hline $\begin{array}{l}\text { Pencatatan Saham Pendiri } \\
\text { (Company Listing) }\end{array}$ & 16.900 .000 .000 & 14-Jul-2003 \\
\hline $\begin{array}{l}\text { Penghapusan Sebagian } \\
\text { (Partial Delisting) }\end{array}$ & -9.955 .000 & 06-Des-2005 \\
\hline $\begin{array}{l}\text { Total Konversi MSOP I, II \& III } \\
(2004-2010)\end{array}$ & 996.449 .742 & \\
\hline Penawaran Terbatas (Right Issue I) & 2.313 .505 .257 & 02-Mar-2011 \\
\hline Tidak dicatatkan (Unlisted) & 233.333 .334 &
\end{tabular}

Sumber: Britama, 20 Desember 2016

Pertumbuhan yang luar biasa ini mencerminkan apresiasi pasar yang positif atas kinerja PT. Bank Mandiri (Persero) Tbk, tapi di sisi lain volatilitas saham menjadi rendah 
karena investor retail mengalami kesulitan pendanaan untuk berinvestasi saham BMRI sehingga diperlukan penilaian saham BMRI perlu dilakukan untuk menentukan harga wajar saham dengan cara membandingkan nilai intrisik terhadap harga pasar saham, sehingga dapat diketahui apakah saham dalam kondisi undervalue atau overvalue. Penentuan harga wajar saham investor dapat membantu pengambilan keputusan investasi yang tepat pada saham BMRI. Tujuan yang ingin dicapai dalam penelitian ini adalah: (1) menentukan nilai wajar (intrinsic value) dengan menggunakan Relative Valution, (2) memperbandingkan harga pasar saham terhadap harga wajar (intrisic value) dengan menggunakan Relative Valuation, (3) menentukan keputusan investasi pada saham PT. Bank Mandiri (Persero)Tbk (BMRI) yang tepat.

\section{Metodologi}

\subsection{Objek Penelitian}

Obyek penelitian ini adalah PT Bank Mandiri (Persero) Tbk (BMRI). Pemilihan PT. Bank Mandiri (Persero) Tbk, sebagai objek penelitian dilakukan secara purposive (disengaja).

\subsection{Sumber Data dan Periode Penelitian}

Data-data yang digunakan dalam penelitian ini adalah data-data sekunder (data historis) yang diperoleh dari berbagai sumber. Data-data yang digunakan dalam penelitian ini adalah sebagai berikut: variabel ekonomi makro Indonesia, seperti pertumbuhan ekonomi, tingkat suku bunga, inflasi, laporan keuangan PT. Bank Mandiri (Persero) Tbk, data statistik saham yang dipublikasikan oleh Bursa Efek Indonesia, Data Indeks Harga Saham Gabungan (IHSG) tahun 2013 sampai dengan Desember 2016 yang digunakan untuk melihat return dari pasar.

\subsection{Metode Pengolahan Data}

Alat statistik yang digunakan dalam pengolahan data penelitian ini menggunakan pendekatan Relative Valuation dari saham PT. Bank Mandiri (Persero) Tbk, yang diperbandingkan dengan harga pasar harga saham saat ini, akan didapatkan overvalue atau undervalue dari saham PT. Bank Mandiri (Persero) Tbk.

\section{Hasil dan Pembahasan}

\subsection{Analisis Makro Ekonomi}

Perekonomian global pada tahun 2016 mengalami ketidakpastian, beberapa negara maju mengalami keterlambatan atau bahkan mengalami penurunan pertumbuhan ekonomi, tetapi Indonesia berhasil mempertahankan pertumbuhan ekonomi yang cukup tinggi.

\section{Produk Domestik Bruto}

Produk Domestik Bruto (PDB) merupakan jumlah nilai tambah yang dihasilkan oleh seluruh unit usaha dalam suatu negara atau wilayah tertentu, atau merupakan jumlah nilai barang dan jasa akhir yang dihasilkan oleh seluruh unit ekonomi. PDB menjadi indikator penting negara maupun wilayah tertentu untuk mengetahui kondisi ekonomi dalam suatu periode tertentu. Perolehan PDB atas dasar harga berlaku dapat dilihat pada Gambar 1 sebagai berikut: 


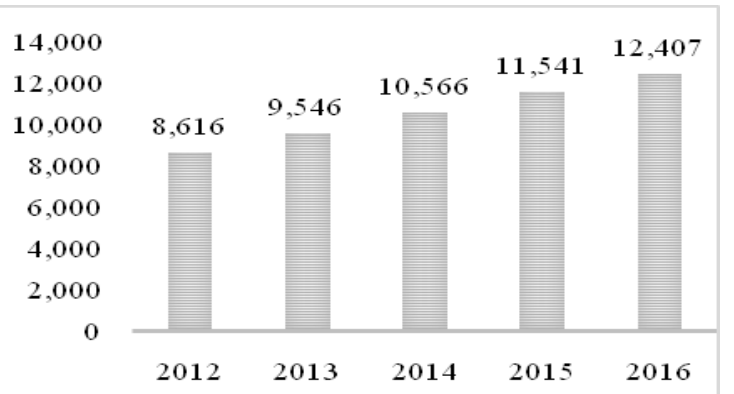

Gambar 1. Grafik Perolehan PDB Seri 2010 atas Harga Berlaku (dalam Triliun Rupiah) Sumber: http://bps.go.id, data hasil olahan penulis, 18 April 2016

\section{Tingkat Inflasi}

Berdasarkan data yang telah dirilis oleh Badan Pusat Statistik (BPS) terjadi trend penurunan tingkat inflasi dari tahun 2013- 2016 yang berdampak pada iklim investasi yang kondusif di Indonesia.Laju inflasi Indonesia tahun 2012 hingga tahu 2016 dapat dilihat pada Gambar 2 sebagai berikut:

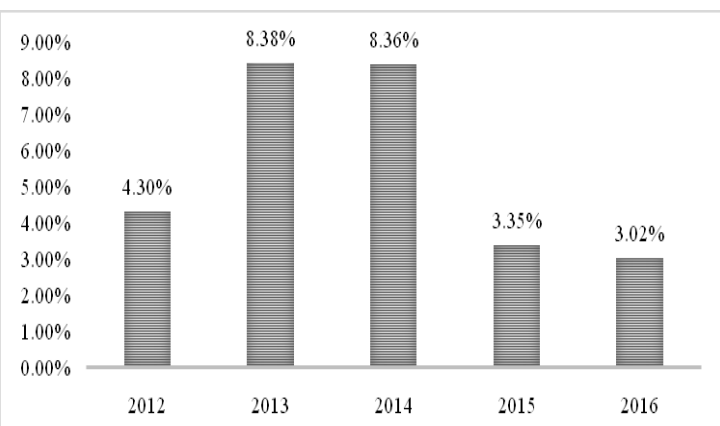

Gambar 2. Laju Inflasi Indonesia Tahun 2012-2016

Sumber: http:// bi.go.id, data diolah penulis, 28 Maret 2016

\section{Nilai Tukar Rupiah}

Rencana kenaikan suku bunga bank sentral Amerika (The Federal Reserve) 2016 yang memicu apresiasi dolar dan menjadi hambatan bagi rupiah untuk menguat lebih lanjut. Kecemasan terhadap kebijakan pemerintah Amerika Serikat terpilih yang cenderung protektif kembali memancing ketidakpastian di pasar finansial global. Pergerakan nilai tukar rupiah sepanjang 2016 mengalami trend penguatan hingga mendekati level Rp 13.000,- per dolar Amerika Serikat (AS). Pergerakan nilai tukar rupiah terhadap dolar AS tahun 2012 hingga 2016 dapat dilihat pada Gambar 3 sebagai berikut:

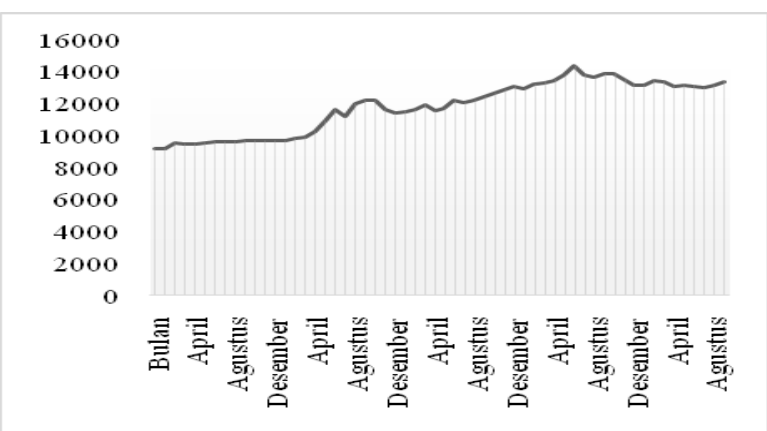

Gambar 3. Laju Pergerakan Nilai Tukar USD terhadap Rupiah Sumber: http://bi.go.id, data hasil olahan penulis, 10 April 2017 


\subsection{Analisis Industri}

Perekonomian Indonesia relatif membaik, namun fungsi intermediasi perbankan nasional pada tahun 2016 masih relatif lemah. Hal tersebut tercermin dari pertumbuhan kredit yang hanya sebesar $7,9 \%$, lebih rendah dibanding pertumbuhan tahun sebelumnya yang mencapai 10,4\%. Sementara itu, Dana Pihak Ketiga (DPK) tumbuh 9,6\%. Salah satu kontributor pertumbuhan DPK adalah program amnesti pajak. Sekitar $71 \%$ dana repatriasi masih mengendap di perbankan. Sisanya, terpecah di berbagai instrumen lain.

\subsection{Analisis Perusahaan Analisis Kualitatif}

Analisis perusahaan dilakukan secara kualitatif dengan menganalisis model bisnis BMRI, posisi BMRI dalam industri, keunggulan kompetitif, manajemen, tata kelola perusahaan, strategi bisnis. Keunggulan kompetitif Bank Mandiri mendukung program Nawacita yang dicanangkan Presiden Republik Indonesia, melalui program pembiayaan bagi berbagai proyek infrastruktur. Tahun 2016 Bank Mandiri menambah kategori baru yaitu Fintech, para wirausaha muda di bidang fintech berkesempatan memperoleh pembinaan dan dukungan pembiayaan bagi pengembangan bisnis melalui PT Mandiri Capital Indonesia.

Fokus bisnis Bank Mandiri pada tahun 2016 dibagi menjadi 3 (tiga) yaitu: (1) Fokus pada core competence awal, meningkatkan porsi fee based income dan Current Account Saving Account (CASA) wholesale melalui penyempurnaan layanan transaction banking dan cash management, (2) Mengembangkan core competence yang baru dan (3) memperkuat fundamental .

\section{Analisis Kuantitatif}

Analisis perusahaan dilakukan secara kuantitatif, yaitu dengan menganalisis laporan keuangan (financial statement) yang secara umum, kondisi keuangan perusahaan apabila dilihat dari akun-akun yang ada pada financial statement dengan periode tahun 2013 sampai tahun 2016 dapat dilihat pada Tabel 2 berikut ini:

Tabel 2. Ikhtisar Keuangan Bank Mandiri (Persero) Tbk

\begin{tabular}{lcccr}
\hline \multirow{2}{*}{ Keterangan } & 2013 & 2014 & 2015 & 2016 \\
\cline { 2 - 5 } Total Aset & 733,100 & 855,040 & 910,063 & 1,039 \\
\hline Total Liabilitas & 644,309 & 750,195 & 736,199 & 824,560 \\
\hline Total Ekuitas & 88,791 & 104,845 & 119,492 & 153,370 \\
\hline Pendapatan Operasional & 23,552 & 25,978 & 26,339 & 18,613 \\
\hline Laba Tahun Berjalan & 17,996 & 21,483 & 20,447 & 40,345 \\
\hline
\end{tabular}

Sumber: Annual Report BMRI tahun 2016

\section{Penilaiaan Harga Wajar Saham BMRI Berdasarkan Relative Valuation}

Pada penelitian ini, Relative Valuation yang digunakan adalah Price Earning Ratio $(P E R)$, Price Book Value $(P B V)$, Price to Cash Flow $(P / C)$, Price to Sales $(P / S)$, dan Economic Value Added (EVA). 


\section{1) Penilaiaan Harga Wajar Saham BMRI Berdasarkan Price Earning Ratio} berikut:

Berikut hasil perhitungan nilai PER saham BMRI dapat dilihat pada Tabel 3 sebagai

Tabel 3. Perhitungan nilai PER saham BMRI

\begin{tabular}{ccccc}
\hline Tahun & 2013 & 2014 & 2015 & 2016 \\
\hline EPS (Rp per lembar) & 780.16 & 851.66 & 871.50 & 591.71 \\
\hline Harga Saham (Rp) & 7,850 & 10,775 & 9,250 & 11,575 \\
\hline PER (Kali) & 10.06 & 12.65 & 10.61 & 19.56 \\
\hline
\end{tabular}

Sumber: Annual Report BMRI tahun 2016, data hasil olahan peneliti, September 2017.

Berdasarkan Tabel 3 nilai Price Earning Ratio BMRI fluktuatif pada periode tahun 2013 hingga 2016, nilai PER berada lebih dari 10, mengindikasikan bahwa harga saham BMRI overvalue terhadap nilai intriksiknya artiya harga saham dinilai mahal untuk dibeli. Bagi investor yang telah memiliki saham BMRI dapat menjual saham tersebut.

\section{2) Penilaiaan Harga Wajar Saham BMRI Berdasarkan Price Book Value}

Tabel 4. Perhitungan nilai PBV saham BMRI

\begin{tabular}{lcccc}
\hline Tahun & 2013 & 2014 & 2015 & 2016 \\
\hline Total Ekuitas (dlm trilyun) & 8,791 & 104,845 & $11, .492$ & 153,370 \\
\hline Jumlah Saham Beredar (dlm trilyun) & 2,333 & 2,333 & 2,333 & 2,333 \\
\hline Harga Saham & 7,850 & 10,775 & 9,250 & 11,575 \\
\hline BV per Share & 3,805 & 4,493 & 5,121 & 6,573 \\
\hline PBV & 2.06 & 2.40 & 1.81 & 1.76 \\
\hline
\end{tabular}

Sumber: Annual Report BMRI tahun 2016

Berdasarkan nilai PBV BMRI dapat dikatakan undervalue pada dua tahun terakhir.

\section{3) Penilaiaan Harga Wajar Saham BMRI Berdasarkan P/C Ratio}

Hasil penilain harga ajar BMRI berdasarkan $P / C$ ratio, dapat dilihat pada Tabel 5 berikut ini:

Tabel 5. Perbandingan nilai P/C Ratio saham BMRI

\begin{tabular}{ccccc}
\hline Tahun & 2013 & 2014 & 2015 & 2016 \\
\hline Operating Cash Flow (dlm trilyun) & 12,734 & 21,092 & 10,202 & 41,521 \\
\hline Jumlah Saham Beredar (dlm trilyun) & 2,333 & 2,333 & 2,333 & 2,333 \\
\hline Harga Saham & 7.850 & 10.775 & 9.250 & 11.575 \\
\hline OCF per Share & 545,72 & $90, .93$ & 437,21 & $1.779,48$ \\
\hline P/C Ratio & 14,38 & 11,92 & $2, .16$ & 6,50 \\
\hline
\end{tabular}

Sumber: Annual Report BMRI tahun 2016 
Berdasarkan Tabel 5 diketahui bahwa nilai P/C Ratio saham BMRI fluktuatif setiap tahunnya. Investor akan menyukai nilai P/C Ratio yang kecil, karena nilai $\mathrm{P} / \mathrm{C}$ yang tinggi mengindikasikan bahwa perusahaan diperdagangkan dengan harga tinggi namun tidak menghasilkan arus kas yang cukup untuk mendukung (multiple).

\section{4) Penilaiaan Harga Wajar Saham BMRI Berdasarkan Economic Value Added}

Invested capital merupakan penjumlahan dari total equity dan total liabilitas dikurangi hutang jangka pendek BMRI. Ketiga komponen tersebut merupakan keseluruhan modal yang digunakan oleh perusahaan dalam menjalankan usahanya. Perhitungan invested capital perusahaan periode tahun 2013-2016 dapat disajikan dalam tabel 6 sebagai berikut:

\begin{tabular}{ccccc}
\multicolumn{4}{c}{ Tabel 6. Hasil Perhitungan Nilai Econoomic Value Added BMRI Tahun 2013-2016 } \\
\hline Tahun & 2013 & 2014 & 2015 & 2016 \\
\hline Invested Capital (dlm Trilyun) & 88,79 & 104,85 & 119,49 & 153,37 \\
\hline WACC & 0,04 & 0,05 & 0,05 & 0,06 \\
\hline Capital Change(dlm Trilyun) & 3,993 & 5,250 & 5,790 & 9.407 \\
\hline Laba Tahun Berjalan(dlm Trilyun) & 17,996 & 2,483 & 20,447 & 40,345 \\
\hline EVA(dlm Trilyun) & 14,003 & 16,233 & 14,657 & 30,938 \\
\hline
\end{tabular}

Sumber : Annual Report BMRI tahun 2016

Berdasarkan Tabel 6 diketahui bahwa nilai Economic Value Added (EVA) saham BMRI berfluktuasi, tetapi nilai EVA saham BMRI selalu lebih dari angka satu dan tidak bernilai kurang dari nol, hal tersebut mengindikasikan bahwa BMRI berhasil memperoleh nilai tambah ekonomis. Setiap tahunnya nilai EVA BMRI fluktuatif, namun BMRI tetap mampu menciptakan nilai ekonomis perusahaan.

\section{Keputusan Investasi bagi Investor}

Setiap investor memiliki preferensi yang berbeda terhadap keuntungan serta risiko yang diinginkan, kemudian investor akan menerapkan strategi investasi yang sesuai dengan profil investor untuk menentukan keputusan investasi yang efektif dan efisien. Berdasarkan hasil perhitungan rasio PER, P/C Ratio Nilai PBV saham BMRI overvalue, akan tetapi jika dilihat dari nilai PBV mengindkasikan bahwa saham BMRI dalam kondisi undervalue dan layak untuk dibeli.

BMRI selama tahun 2013 hingga tahun 2016 mampu mencapai Economic Value Added yang bernilai positif. Nilai Economic Value Added BMRI fluktuatif pada setiap tahunnya selama empat tahun terakhir. Hal tersebut mengindikasikan bahwa manajemen dinilai berhasil dalam menjalankan tugasnya. Kinerja tersebut dapat mendorong keyakinan dan kepercayaan investor untuk menanamkan dana pada saham BMRI, walaupun secara umum overvalue dengan melihat trend rasio EVA dan potensi dimasa yang akan datang ini adalah saat yang tepat untuk melakukan profit taking dan melakukan pembelian saham BMRI tersebut.

\section{Kesimpulan dan Saran \\ Kesimpulan}

1) Nilai intrinsik saham BMRI yang dihitung dengan metode Relative Valuation, pada tahun 2016 saham BMRI dapat diindikasikan overvalue di pasar.

2) Manajemen BMRI berhasil menciptakan nilai tambah ekonomi dalam menjalankan bisnis perusahaan. 
3) Keputusan investasi yang dapat diambil investor terhadap saham BMRI dapat berdasarkan hasil perhitungan nilai intrinsik saham BMRI dengan metode Relative Valuation adalah menunda untuk membeli saham BMRI.

\section{Saran}

Saran yang dapat diberikan berdasarkan hasil penelitian ini adalah sebagai berikut:

1) Perusahaan dapat melihat bahwa harga saham BMRI di pasar yang telah overvalue, sehingga manajemen disarankan untuk melakukan aksi korporasi yang tepat untuk menstabilkan harga saham BMRI.

2) Berdasarakan hasil perhitungan valuasi BMRI, saham dinilai overvalue, sehingga dapat menjadi salah satu alternatif investasi bagi investor, karena perusahaan memiliki fundamental yang baik.

3) Diharapkan bagi penelitian selanjutnya untuk mempertimbangkan adanya risiko apabila pertumbuhan tidak seperti yang diasumsikan.

\section{Daftar Pustaka}

Asnawi, Said Kelana dan Chandra Wijaya. 2010. Pengantar Valuasi. Salemba Empat:Jakarta.

Brigham, F. Eugene dan Michael C. Ehrhardt. 2010Financial management: Theory and practice. South Western. Ohio.

Britama. 2016. Sejarah dan Profil Singkat BMRI.

http://www.britama.com/index.php/2012/10/sejarah-dan-profil-singkat-BMRI/. 20 Oktober 2016.

Darmadji, Tjipto dan Hendry, M Fakhruddin. 2001. Pasar Modal di Indonesia. Salemba Emapat: Jakarta.

Bariksa.com 2017. Saham BMRI Naik Hampir 2000 Persen, Bank Mandiri Akan Stock Split

http://www.bareksa.com/id/text/2017/08/08/saham-bmri-naik-hampir-2000-persen-sejak-ipobank-mandiri-akan-stock-split/16230/analysis._8 Agustus 2017.

Husnan, S. 2005. Dasar- Dasar Teori Portofolio dan Analisis Sekuritas. EdisiKetiga. Unit Penerbit dan Percetakan UNP YKPN. Yogyakarta.

Jogiyanto, H.M. 2010. Teori Portofolio dan Analisis Investasi. Edisi Ketujuh.BPFE.Yogyakarta.

Noor,M. Sayyidin dan Satyawan, Made Dudy. 2014. "Analisis Penilaian Harga Wajar Saham (Studi Kasus pada PT Multi Bintang Indonesia,tbk)”.Jurnal Ilmu Manajemen. Volume 2, Nomor 3 Juli, Surabaya.

Perolthen ,Clara Naomi dan Moellno, Nadya. 2015. Analisis Penilaian Harga Wajar Saham Bank Tabungan Negara Periode 2015.Prodi Administrasi Bisnis Fakultas Komunikasi dan Bisnis. Universitas Telkom.

Putra, I Putu Darma. 2009. “Analisis Valuasi Saham pada PT Indofood Sukses Makmur Tbk, PT Gudang Garam Tbk, dam PT Unilever Tbk”.Universitas Gunadarma.

Sukirno, Sadono. 2011. Makro Ekonomi Teori Pengantar. Edisi Ketiga. PT Raja Grafindo Persada : Jakarta.

Tandelilin, Eduardus, 2007. Analisis Investasi dan Manajemen Portofolio.Yogyakarta : BPFE. 